\title{
Development of near isogenic lines (NILS) using backcross method of breeding and simultaneous screening against Karnal bunt disease of wheat
}

\author{
Indu Sharma ${ }^{1}$, Ritu Bala ${ }^{1}$, Satish Kumar ${ }^{2 *}$ and N. S. Bains ${ }^{2}$ \\ ${ }^{1}$ ICAR - Indian Institute of Wheat and Barley Research, Karnal - 132001 (Haryana), INDIA \\ ${ }^{2}$ Punjab Agricultural University, Ludhiana - 141004 (Punjab), INDIA \\ *Corresponding author. E-mail: kumarsatish227@gmail.com
}

Received: September 22, 2015; Revised received: March 30, 2016; Accepted: July 02, 2016

\begin{abstract}
Karnal bunt of wheat caused by Tilletia indica can be a hindrance to wheat trade as the fungal disease is known to affect the quality of the grain. As a breeding strategy, a set of eight near isogenics lines (NILs) and backcross derived recombinant inbred lines (micro-RILs) were developed in the background of PBW 343 and WH542 for Karnal bunt resistance over a period of time. The donor stocks resistant to Karnal bunt used in the study were ALDAN ' S' / IAS 58, CMH 77.308, H567.7I, HD29, HP1531, W485 and their derived lines KBRL 22 and KBRL 57. Effective method for screening to Karnal bunt was standardized and used for identification of resistant lines across many seasons. Some of the identified lines evaluated for yield were found to be equivalent to the high yielding parents and the commercially grown check varieties. These developed lines will serve as a basic material for production of Karnal bunt free wheat.
\end{abstract}

Keywords: Karnal bunt, Near isogenic lines (NILs), Tilletia indica, Micro-RILs, Resistance

\section{INTRODUCTION}

Karnal bunt of wheat was first reported from Karnal (Haryana) in 1931 by Mitra and is hence named after the place. The disease is caused by a fungus, Tilletia indica (Mitra) and is also called as partial bunt. Under natural conditions the disease caused by fungus ( $T$. indica) infects bread wheat, durum wheat and triticale (Triticosecale). However artificially it can be induced on ryes (Secale cereale) and several other wild and related species of Triticum, Aegilops, Bromus, Lolium and Oryzopsis (Warham, 1986; Gill et al., 1993). Within India the pathogen is widespread in northern and central India viz. Delhi, Uttar Pradesh, Haryana, Punjab, Himachal Pradesh, Rajasthan, Madhya Pradesh, Jammu and Kashmir, West Bengal and Gujarat (Singh et al., 1985). The first report of Karnal bunt from a non-Asian country came from Mexico in 1972, where the disease has been reported from localized areas (Duran and Cromarty, 1977).

The diagnosis of this disease is difficult as the infection is random in distribution. Detection of the diseased ear head is also cumbersome since few ear heads are infected. Also in an infected ear head, only some spikelets bear bunted grains. Infection in the grains is either incipient or it gets extended to the whole grains under favourable environmental conditions. In artificially inoculated ear heads, the disease can be identified when the grains are still green. Before turning pale, the glumes of infected spikes give silvery shine and also spread apart due to accumulation of telio- spores. In India, the months of February and March when temperature and moisture are congenial and the crop is at its susceptible stage, the sporidia infection takes place. The optimum temperature for multiplication of allantoid sporidia and infection is $18-22^{\circ} \mathrm{C}$ and $>80 \%$ relative humidity. It takes longer incubation period at lower temperature. Range of average temperature in areas where disease is prevalent varies from $5-25^{\circ} \mathrm{C}$ (Krishna and Singh, 1982).

Management of Karnal bunt disease requires an integrated approach, wherein cultural practices and resistance breeding are known to control the disease effectively. Different methods for the control of Karnal bunt have been advocated such as quarantine regulations (Sansford et al, 2008), spray of fungicides such as Propiconazole @ 0.1\% at heading stage (Sharma, 2004), seed treatment (Smilanick et al., 1987a; 1987b), cultural practices (Sharma et al., 2007) and host plant resistance - most economically viable, environmental friendly, cost effective method for the control of plant diseases.

Efforts for resistance breeding work on Karnal bunt were carried out since the standardization of inoculation technique in early 1980s. KB incidence above zero falls short of quarantine requirements thus there exists no threshold level for this disease. Hence high levels of resistance are desired. However, few wheat lines were found to be highly resistant or immune to the disease (Gill et al., 1981). Subsequently as a practical norm, test lines showing up to $5 \%$ infection were 
rated to be resistant (Aujla et al., 1985). Resistance was also identified in Secale cereale, Triticale, several accessions of Aegilops spp, Ae. biuncialis, Ae. columaris, Ae. crassa, Ae. jubenalis, Ae. ovata, Ae. speltoides T. uratu and Ae. squarosa ((Warham, 1986, Villareal et al., 1994; 1996 and Sharma et al., 2012) reported high degree of resistance to $\mathrm{KB}$ in synthetic hexaploid wheats derived from the crosses of $T$. turgidum and T. tauschii. Four synthetic wheat lines, SH12 (Altar84/T.tauschii-Acc.198), SH46 (Duergand/ T.tauschii-Acc.221), SH10 (Altar84/T.tauschiiAcc.223) and SH31 (Chen'S'/T.tauschii-Acc.224) were registered for Karnal bunt resistance. At CIMMYT, Mexico, wheat varieties, viz; LUAN, CATBIRD, INIFAB and TOBARITO released for commercial cultivation were KB tolerant (Fuentes-Davila and Rajaram, 1994).

Based on screening for Karnal bunt at PAU, Ludhiana for more than 20 years, lines showing resistance to Karnal bunt were identified. KB resistant lines identified were included in national genetic stock nursery under AICWIP. Two such stocks HD 29 and HD 30 were registered under AICWIP in the year 1999 to be resistant to Karnal bunt. Later durum wheat (D 482, D 873, D 879, D 895) and triticale (TL2807) lines from PAU-Ludhiana were also registered for KB resistance with NBPGR. In this study we describe in details the methodology used to develop near isogenic lines (NILs) and backcross derived recombinant inbred lines (micro-RILs) in the background of high yielding wheat cultivars, PBW 343 and WH542 (Table 1). These Karnal bunt resistant lines can be useful for utilization in wheat breeding programs. Production of Karnal bunt free wheat can pave way for export of Indian wheats to the developed countries.

\section{MATERIALS AND METHODS}

The present investigation was carried out at the experimental farms of PAU, Ludhiana and PAU Off-season Research Station, Keylong (HP). The culture development and preparation of fungal inoculum was carried out at the field laboratory of wheat section, PAU, Ludhiana. Development of populations and the establishment of Karnal bunt resistance in near isogenic lines of six crosses in the background of WH542 and two crosses in the background of PBW 343 were carried out under different experiments. A set of Karnal bunt resistant stocks developed at PAU, Ludhiana (Table 1) have already been registered with National Bureau of Plant Genetic Resources. Various materials used and methods employed to carry out this investigation are described below:

The plant material: The plant material for the study is based on populations/generations derived from the following crosses:

PBW343/6*/KBRL22

PBW343/6*/KBRL57
WH542*5//ALDAN' S'/IAS58

WH542*5/CMH77.308

WH542*5/H 567.7I/3*PAR

WH542*5/HD29

WH542*5/HP1531

WH542*5/W485

Population development: The donor parents for resistance to Karnal bunt were ALDAN ' $\mathrm{S}$ ' / IAS 58, CMH 77.308, H567.7I, HD29, HP1531, W485, KBRL 22 and KBRL 57. Both KBRL 22 (HD 29/W 485) and KBRL 57 (ALDAN 'S' / IAS 58 x H 567.71) combine diverse resistance genes from the two different stocks and is evident from their high degree of resistance $(0 \%$ infection levels for $\mathrm{KB}$ ) compared to infection up to $5 \%$ in the parental stocks (Sharma et al, 2001; 2004). Crosses were made to transfer $\mathrm{KB}$ resistance from KBRL 22 and KBRL 57 into high yielding wheat cultivar PBW 343, whereas the parental stocks ALDAN ' S' / IAS 58, CMH 77.308, H567.7I, HD29, HP1531 and W485 were crossed with WH 542. The $\mathrm{F}_{1}$ 's so obtained were backcrossed with the high yielding parent for development of near isogenic lines. In each backcross generation, about 150 plants were simultaneously screened against $\mathrm{KB}$ and involved in backcrossing with PBW 343 and WH 542. Backcross seed, set on KB free plants was retained for growing in the next season. Subsequently selfing and backcrossing was carried out upto $\mathrm{BC}_{6} \mathrm{~F}_{1}$ for $\mathrm{PBW} 343$ populations and $\mathrm{BC}_{5} \mathrm{~F}_{1}$ for $\mathrm{WH} 542$ populations. At each backcross stage the plants were inoculated with fungal spores of Tilletia indica and resistant plants identified. Finally, $\mathrm{BC}_{6} \mathrm{~F}_{1}$ and $\mathrm{BC}_{5} \mathrm{~F}_{1}$ plants derived from backcross of resistant individuals were screened for $\mathrm{KB}$ resistance and the resistant plants were advanced to get subsequent $\mathrm{F}_{2}$ generations. At each generation of advancement the plants were screened artificially by syringe method of inoculation. To hasten up the generation advancement, off-season station at Keylong (HP) was utilized. The resistant plants identified in $\mathrm{BC}_{3} \mathrm{~F}_{2}, \quad \mathrm{BC}_{4} \mathrm{~F}_{2}$ and $\mathrm{BC}_{5} \mathrm{~F}_{2}$ were further selfed and subjected to artificial screening with $\mathrm{KB}$ upto $\mathrm{BC}_{3} \mathrm{~F}_{6}$, $\mathrm{BC}_{4} \mathrm{~F}_{6}$ and $\mathrm{BC}_{5} \mathrm{~F}_{6}$ generations. These established back cross derived near isogenic lines were subjected to screening under artificial inoculations (Aujla et al., 1982).

Artificial inoculation of the crop: Seventeen previously collected and well established $T$. indica isolates representing genetic variability prevalent in North Western Plains Zone (NWPZ) of India were used for the present study. The isolation, multiplication and maintenance of pathogen were done on Potato Dextrose Agar (PDA) medium.

Artificial inoculation of wheat was done following "Syringe inoculation method" given by Aujla et al., (1982). Inoculum was prepared by mixing all the seventeen isolates in equal proportions for screening work. For preparing the inoculum suspension, steril- 
ized distilled water was added to the test tubes and with the help of a glass rod the fungal sporidia was gently scraped to remove allantiod secondary sporidia. Inoculum suspension was then filtered through double layer of muslin cloth and its concentration was adjusted at more than 10,000 sporidia /ml. Similar procedure was followed for preparing sporidial suspension

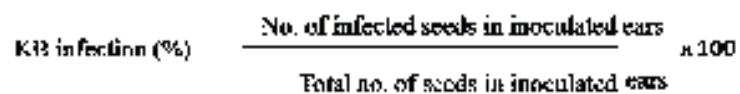

for further experiments. The plants were inoculated at boot stage invariably during the evening hours. To ensure maximum humidity, the frequent irrigation was given in the field. In each population 100-150 plants along with parents were inoculated and 4-5 ears per plant were inoculated.

Inoculated wheat ears were harvested and percentage disease infection was recorded as follows:

Data were recorded as percent infection per plant. Plants within each population of crosses were categorized into Resistant $(\mathrm{R})$ i.e. with disease reactions matching with those of the resistant parent and Susceptible (S) i.e. with disease reactions matching with those of the susceptible parent and other intermediate categories.

\section{RESULTS AND DISCUSSION}

The backcross derived recombinant populations of PBW343 and WH542 were used to identify agronomically superior Karnal bunt resistant plants. In each of the eight crosses, at least ten extreme resistant and susceptible progenies were identified on the basis of average score of the individual plants, and NILs were designated in each cross as follows:

KBRL22 $x$ PBW 343: During the present study $\mathrm{BC}_{6} \mathrm{~F}_{6}$ population derived from KBRL 22/PBW 343 cross was sown as progenies in the field during Rabi 20012-13. A total of 371 progenies were sown (each progeny consisting of 10-15 plants). In each progeny, a total of 4-5 ear heads were inoculated per plant. The inoculated ear heads were harvested and threshed manually and percent Karnal bunt infection was calcu-
Table 1. Stocks having high degree of Karnal bunt resistance

\begin{tabular}{ll}
\hline \multicolumn{1}{c}{ Parental Cross } & KB-free lines (designated) \\
\hline HD 29/W 485 & $\begin{array}{l}\text { KBRL8, KBRL14, KBRL16, } \\
\text { KBRL22, KBRL24 }\end{array}$ \\
ALDAN 'S' / IAS & KBRL 57 \\
58/H 567.71 'S'/IAS & KBRL 63 \\
ALDAN 'S7.308 & \\
58/CMH 77. \\
H 567.71/3*PAR/ & KBRL 68 \\
HP 1531 & \\
H 567.71/3*PAR/ & KBRL 67 \\
CPAN 3045 & \\
HD 29/CPAN 3045 & KBRL 69 \\
HD 29/CMH & KBRL 70 \\
77.308 29/H & KBRL 60 \\
HD 567.71/3*PAR & \\
\hline
\end{tabular}

lated. Out of these 371 progenies, only 27 were homozygous resistant, 237 were heterozygous, while 107 were homozygous susceptible. From these ten extreme resistant and ten extreme susceptible progenies were identified for NIL development. The percent Karnal bunt infection of ten extreme resistant and extreme susceptible progenies were identified in this cross is given in the Table 2. As evident from the table 2, the selected resistant progenies showed a range of Karnal bunt infection from 0.00 to 0.53 percent. In some of the progenies which were selected as extreme resistant there were plants showing susceptibility. This may be due to the variation in the pathogen population or environment. Moreover, those five inoculated plants which were carried forward to $\mathrm{BC}_{6} \mathrm{~F}_{6}$ for NIL development were those which have a score of less than 0.20 percent. Selection for extreme susceptible progenies was also done on the basis of per cent Karnal bunt infection. All the selected plants had a Karnal bunt score of $>40.00$ percent. These five resistant and susceptible plants were sown as progenies in $\mathrm{BC}_{6} \mathrm{~F}_{6}$. From these progenies individual plants were identified on the basis of percent Karnal bunt infection and were advanced further for NIL development.

i)KBRL57 x PBW 343: The $\mathrm{BC}_{6} \mathrm{~F}_{5}$ population derived from KBRL 57/PBW 343 cross was sown as progenies

Table 2. Extreme resistant and extreme susceptible NILs identified in $\mathrm{BC}_{6} \mathrm{~F}_{6}$ population of KBRL22/PBW 343 on the basis of per cent Karnal bunt infection.

\begin{tabular}{cccc}
\hline Highly resistant NILs & $\begin{array}{c}\text { Karnal bunt } \\
\text { Infection }(\boldsymbol{\%})\end{array}$ & Highly Susceptible NILs & $\begin{array}{c}\text { Karnal bunt } \\
\text { Infection }(\boldsymbol{\%})\end{array}$ \\
\hline C7-R1-5-1 & 0.18 & C7-S1-3-1 & 52.34 \\
C7-R1-5-2 & 0.00 & C7-S1-3-2 & 48.34 \\
C7-R1-5-3 & 0.15 & C7-S1-3-3 & 55.32 \\
C7-R1-5-4 & 0.48 & C7-S1-3-4 & 48.31 \\
C7-R1-5-5 & 0.53 & C7-S1-3-5 & 49.21 \\
C7-R5-9-2 & 0.40 & C7-S4-5 -1 & 48.25 \\
C7-R5-9-3 & 0.48 & C7-S4-5 -2 & 65.01 \\
C7-R5-9-4 & 0.20 & C7-S4-5 -3 & 49.50 \\
C7-R5-9-5 & 0.00 & C7-S4-5 -4 & 45.66 \\
C7-R6-4-1 & 0.00 & C7-S4-5 -5 & 46.32 \\
\hline
\end{tabular}


Indu Sharma et al. / J. Appl. \& Nat. Sci. 8 (3): 1138 - 1145 (2016)

Table 3. Extreme resistant and extreme susceptible NILs identified in $\mathrm{BC}_{6} \mathrm{~F}_{6}$ population of KBRL57/PBW 343 on the basis of per cent Karnal bunt infection

\begin{tabular}{cccc}
\hline Highly resistant NILs & $\begin{array}{c}\text { Karnal bunt } \\
\text { Infection }(\%)\end{array}$ & Highly Susceptible NILs & $\begin{array}{c}\text { Karnal bunt } \\
\text { Infection }(\%)\end{array}$ \\
\hline C8-R2-3-1 & 0.00 & C8-S1-1-1 & 42.85 \\
C8-R2-3-2 & 0.10 & C8-S1-1-2 & 40.34 \\
C8-R2-3-3 & 0.23 & C8-S1-1-3 & 45.42 \\
C8-R2-3-4 & 0.00 & C8-S1-1-4 & 55.31 \\
C8-R2-3-5 & 0.61 & C8-S1-1-5 & 41.21 \\
C8-R2-3-6 & 0.00 & C8-S7-4 -1 & 51.23 \\
C8-R5-4-1 & 0.00 & C8-S7-4 -2 & 52.43 \\
C8-R5-4-2 & 0.28 & C8-S7-4 -3 & 42.56 \\
C8-R5-4-3 & 0.20 & C8-S7-4 -5 & 55.61 \\
C8-R5-4-4 & 0.00 & 54.78 \\
\hline
\end{tabular}

Table 4. Extreme resistant and extreme susceptible NILs identified in $\mathrm{BC}_{5} \mathrm{~F}_{6}$ population of WH542*5/ALDAN ' $\mathrm{S}$ ' / IAS 58 on the basis of per cent Karnal bunt infection.

\begin{tabular}{cccc}
\hline Highly resistant NILs & $\begin{array}{c}\text { Karnal bunt } \\
\text { Infection }(\%)\end{array}$ & Highly Susceptible NILs & $\begin{array}{c}\text { Karnal bunt } \\
\text { Infection }(\%)\end{array}$ \\
\hline C1-R1-1-1 & 1.64 & C1-S2-3-1 & 50.00 \\
C1-R1-1-2 & 0.00 & C1-S2-3-2 & 58.71 \\
C1-R1-1-3 & 1.38 & C1-S2-3-3 & 50.89 \\
C1-R1-1-4 & 0.74 & C1-S2-3-4 & 63.06 \\
C1-R1-1-5 & 0.00 & C1-S2-3-5 & 50.00 \\
C1-R1-1-6 & 0.00 & C1-S2-3-6 & 57.65 \\
C1-R4-2-1 & 0.70 & C1-S2-3-7 & 54.09 \\
C1-R4-2-3 & 3.47 & C1-S5-2-1 & 55.35 \\
C1-R4-2-5 & 0.65 & C1-S5-2-3 & 53.53 \\
C1-R4-2-6 & 0.77 & C1-S5-2-4 & 68.18 \\
C1-R5-4-1 & 0.00 & C1-S7-2-5 & 53.88 \\
C1-R5-4-3 & 0.00 & C1-S7-1-2 & 50.74 \\
C1-R5-4-4 & 0.00 & C1-S7-1-4 & 52.72 \\
C1-R5-4-5 & 0.00 & C1-S7-1-6 & 55.56 \\
\hline
\end{tabular}

in the field during Rabi 2012-13. A total of 251 progenies were sown (each progeny consisting of 10-15 plants). In each progeny, a total of 4-5 ear heads were inoculated per plant. The inoculated ear heads were harvested and threshed manually and percent Karnal bunt infection was calculated. Out of these 251 progenies, only 24 were homozygous resistant, 163 were heterozygous while 64 were homozygous susceptible. From these ten extreme resistant and ten extreme susceptible progenies were identified for NIL development. The percent Karnal bunt infection of ten extreme resistant and extreme susceptible progenies were identified in this cross is given in the Table 3 . As evident from the table 3 , the selected resistant progenies showed a range of Karnal bunt infection from 0.00 to 0.61 percent. In some of the progenies which were selected as extreme resistant there were plants showing susceptibility. This may be due to the variation in the pathogen population or environment. Moreover, those five plants which were carried forward to $\mathrm{BC}_{6} \mathrm{~F}_{6}$ for NIL development were those which have a score of less than 2.00 percent. Selection for extreme suscepti-

Table 5. Extreme resistant and extreme susceptible NILs identified in $\mathrm{BC}_{5} \mathrm{~F}_{6}$ population of $\mathrm{WH} 542 * 5 / \mathrm{CMH} 77.308$ on the basis of per cent Karnal bunt infection.

\begin{tabular}{cccc}
\hline Highly resistant NILs & $\begin{array}{c}\text { Karnal bunt } \\
\text { Infection }(\%)\end{array}$ & Highly Susceptible NILs & $\begin{array}{c}\text { Karnal bunt } \\
\text { Infection }(\%)\end{array}$ \\
\hline C2-R2-3-1 & 2.00 & C2-S5-1-1 & 58.27 \\
C2-R2-3-2 & 0.00 & C2-S5-1-2 & 54.16 \\
C2-R2-3-3 & 0.00 & C2-S5-1-3 & 69.56 \\
C2-R2-3-5 & 0.49 & C2-S5-1-4 & 52.63 \\
C2-R5-1-1 & 0.00 & C2-S5-1-6 & 50.00 \\
C2-R5-1-2 & 0.00 & C2-S6-3-1 & 50.45 \\
C2-R5-1-3 & 0.00 & C2-S6-3-3 & 68.00 \\
C2-R5-1-4 & 0.00 & C2-S6-3-4 & 52.25 \\
C2-R7-3-1 & 4.98 & C2-S6-3-5 & 50.15 \\
C2-R7-3-2 & 0.00 & C2-S6-3-6 & 53.84 \\
C2-R7-3-3 & 0.00 & & 50.54 \\
\hline
\end{tabular}


Table 6. Extreme resistant and extreme susceptible NILs indentified in $\mathrm{BC}_{5} \mathrm{~F}_{6}$ population of WH 542*5/H 567.71/3*PAR on the basis of per cent Karnal bunt infection.

\begin{tabular}{cccc}
\hline Highly resistant NILs & $\begin{array}{c}\text { Karnal bunt } \\
\text { Infection }(\%)\end{array}$ & Highly Susceptible NILs & $\begin{array}{c}\text { Karnal bunt } \\
\text { Infection }(\%)\end{array}$ \\
\hline C3-R1-5-1 & 0.00 & C3-S3-3-1 & 65.11 \\
C3-R1-5-3 & 0.00 & C3-S3-3-2 & 61.49 \\
C3-R1-5-4 & 0.00 & C3-S3-3-3 & 61.53 \\
C3-R1-5-5 & 0.00 & C3-S3-3-4 & 93.75 \\
C3-R1-5-6 & 3.92 & C3-S4-5-3 & 59.42 \\
C3-R3-5-1 & 0.00 & C3-S4-5-4 & 56.16 \\
C3-R3-5-2 & 1.47 & C3-S4-5-5 & 70.39 \\
C3-R3-5-3 & 0.00 & C2-S9-5-1 & 73.49 \\
C3-R3-5-4 & 1.63 & C2-S9-5-3 & 73.47 \\
C3-R3-5-5 & 0.64 & C2-S9-5-5 & 75.00 \\
\hline
\end{tabular}

Table 7. Extreme resistant and extreme susceptible NILs indentified in $\mathrm{BC}_{5} \mathrm{~F}_{6}$ population of WH 542*5/HD 29 on the basis of per cent Karnal bunt infection.

\begin{tabular}{cccc}
\hline Highly resistant NILs & $\begin{array}{c}\text { Karnal bunt } \\
\text { Infection (\%) }\end{array}$ & Highly Susceptible NILs & $\begin{array}{c}\text { Karnal bunt } \\
\text { Infection (\%) }\end{array}$ \\
\hline C4-R7-5-1 & 1.75 & C4-S1-5-1 & 57.88 \\
C4-R7-5-2 & 1.78 & C4-S1-5-2 & 50.00 \\
C4-R7-5-3 & 1.58 & C4-S1-5-3 & 57.36 \\
C4-R7-5-4 & 1.68 & C4-S1-5-4 & 62.39 \\
C4-R7-5-5 & 1.88 & C4-S6-4-1 & 54.54 \\
C4-R10-1-1 & 0.76 & C4-S6-4-2 & 54.82 \\
C4-R10-1-2 & 0.00 & C4-S6-4-3 & 51.80 \\
C4-R10-1-3 & 4.24 & C4-S6-4-4 & 54.28 \\
C4-R10-1-4 & 0.00 & C4-S6-4-5 & 50.80 \\
C4-R10-1-5 & C4-S6-4-6 & 57.94 \\
\hline
\end{tabular}

ble progenies was also done on the basis of percent Karnal bunt infection. All the selected plants had a Karnal bunt score of $>40.00$ percent. These five resistant and susceptible plants were sown as progenies in $\mathrm{BC}_{6} \mathrm{~F}_{6}$. From these progenies individual plants were identified on the basis of percent Karnal bunt infection and were advanced further for NIL development.

ii) WH 542*5//ALDAN ' $\mathrm{S}$ ' / IAS 58: The $\mathrm{BC}_{5} \mathrm{~F}_{5}$ population derived from $\mathrm{WH} 542 * 5 / / \mathrm{ALDAN}$ ' $\mathrm{S}$ ' / IAS 58 cross was sown as progenies. A total of 177 progenies were sown. In each progeny, a total of 4-5 ear heads were inoculated per plant. The inoculated ear heads were harvested and threshed manually and percent Karnal bunt infection was calculated (Table 4). Out of these 177 progenies, only five were homozygous resistant, 157 were heterozygous, while 15 were homozygous susceptible. From these 10 extreme resistant and 10 extreme susceptible progenies were identified for establishment of NILs in WH 542*5//ALDAN 'S' / IAS 58. As evident from the table 4 , the selected resistant progenies showed a range of Karnal bunt infection from zero to 3.47 percent. Selection for extreme susceptible progenies was also done on the basis of per cent Karnal bunt infection. All the susceptible plants had a Karnal bunt score of $>50.00$ percent. The progenies identified as homozygous for resistance and susceptibility were advanced for NIL development.

iii)WH 542*5/CMH 77.308: The $\mathrm{BC}_{5} \mathrm{~F}_{5}$ population derived from WH 542*5/CMH 77.308 cross was sown as progenies. A total of 257 progenies were sown. In each progeny, a total of 4-5 ear heads were inoculated per plant. The inoculated ear heads were harvested and threshed manually and percent Karnal bunt infection was calculated (Table 5). Out of these 257 progenies, only five were homozygous resistant, 233 were heterozygous, while 19 were homozygous susceptible. From these ten extreme resistant and ten extreme susceptible progenies were identified for NIL establishments. The selected resistant progenies showed a range of Karnal bunt infection from zero to 4.98 percent. Selection for extreme susceptible progenies was also done on the basis of per cent Karnal bunt infection. All the inoculated plants had a Karnal bunt score of $>50.00$ per cent. From these progenies, individual plants were identified on the basis of per cent Karnal bunt infection of individual progeny and average score of the progenies for NIL development.

iv)WH $542 * \mathbf{5} / \mathbf{H} \mathbf{5 6 7 . 7 I} / \mathbf{3} * \mathbf{P A R}$ : The $\mathrm{BC}_{5} \mathrm{~F}_{5}$ population derived from WH 542*5/ H 567.7I /3*PAR cross was also sown as progenies. A total of 196 progenies were sown. In each progeny, a total of 4-5 ear heads were inoculated per plant. The inoculated ear heads were harvested and threshed manually and percent Karnal bunt infection was calculated (Table 6). Out of these 196 progenies, three progenies were homozygous resistant, 183 were heterozygous while 10 were homozygous susceptible. From these ten extreme resistant and ten extreme susceptible progenies were identified for NIL establishments. The selected resistant proge- 
Table 8. Extreme resistant and extreme susceptible NILs indentified in $\mathrm{BC}_{5} \mathrm{~F}_{6}$ population of $\mathrm{WH} 542 * 5 / \mathrm{HP} 1531$ on the basis of per cent Karnal bunt infection

\begin{tabular}{cccc}
\hline $\begin{array}{c}\text { Highly resistant } \\
\text { NILs }\end{array}$ & $\begin{array}{c}\text { Karnal bunt } \\
\text { Infection }(\%)\end{array}$ & Highly Susceptible NILs & $\begin{array}{c}\text { Karnal bunt } \\
\text { Infection }(\%)\end{array}$ \\
\hline C5-R3-5-2 & 0.00 & C5-S1-5-1 & 51.13 \\
C5-R3-5-3 & 0.00 & C5-S1-5-2 & 57.39 \\
C5-R3-5-4 & 1.62 & C5-S1-5-3 & 56.03 \\
C5-R3-5-6 & 1.49 & C5-S1-5-4 & 54.65 \\
C5-R7-3-1 & 0.00 & C5-S1-5-6 & 50.81 \\
C5-R7-3-2 & 4.35 & C5-S8-4-1 & 58.14 \\
C5-R7-3-3 & 0.00 & C5-S8-4-3 & 53.10 \\
C5-R7-3-4 & 1.35 & C5-S8-4-4 & 57.69 \\
C5-R9-4-1 & 1.85 & C5-S8-4-5 & 57.69 \\
C5-R9-4-3 & 1.01 & C5-S8-4-6 & 59.69 \\
\hline
\end{tabular}

Table 9. Extreme resistant and extreme susceptible NILs identified in $\mathrm{BC}_{5} \mathrm{~F}_{6}$ population of $\mathrm{WH} 542 * 5 / \mathrm{W} 485$ on the basis of per cent Karnal bunt infection.

\begin{tabular}{cccc}
\hline Highly resistant NILs & $\begin{array}{c}\text { Karnal bunt } \\
\text { Infection }(\%)\end{array}$ & Highly Susceptible NILs & $\begin{array}{c}\text { Karnal bunt } \\
\text { Infection }(\%)\end{array}$ \\
\hline C5-R1-2-2 & 1.93 & C5-S1-5-1 & 59.25 \\
C5-R1-2-3 & 0.78 & C5-S1-5-2 & 55.86 \\
C5-R1-2-5 & 0.00 & C5-S1-5-3 & 50.09 \\
C5-R1-2-6 & 0.00 & C5-S1-5-4 & 60.46 \\
C5-R1-2-7 & 0.00 & C5-S4-5 -1 & 53.29 \\
C5-R6-3-1 & 3.82 & C5-S4-5 -2 & 59.25 \\
C5-R6-3-3 & 0.00 & C5-S4-5 -3 & 55.77 \\
C5-R6-3-4 & 0.00 & C5-S4-5 -4 & 55.39 \\
C5-R6-3-5 & 0.25 & C5-S4-5 -5 & 65.09 \\
\hline
\end{tabular}

nies showed a range of Karnal bunt infection from zero to 3.92 percent. Selection for extreme susceptible progenies was also done on the basis of percent Karnal bunt infection. All the selected plants had a Karnal bunt score of $>50.00$ percent. From these progenies, individual plants were identified on the basis of per cent Karnal bunt infection of individual progeny and average score of the progenies for NIL development.

v)WH 542*5/HD29: The $\mathrm{BC}_{5} \mathrm{~F}_{5}$ population derived from WH $542 * 5 / \mathrm{HD} 29$ cross was sown as progenies in the field. A total of 133 progenies were sown. In each progeny, a total of 4-5 ear heads were inoculated per plant. The inoculated ear heads were harvested and threshed manually and percent Karnal bunt infection was calculated (Table 7). Out of these 133 progenies, only four were homozygous resistant, 126 were heterozygous, while three were homozygous susceptible. From these ten extreme resistant and ten extreme susceptible progenies were identified for NIL establishments. The selected resistant progenies showed a range of Karnal bunt infection from zero to 4.24 percent. Selection for extreme susceptible progenies was also done on the basis of percent Karnal bunt infection. All the selected plants had a Karnal bunt score of $>50.00$ percent. On the basis of percent Karnal bunt score of individual plants and average score of the progenies in $\mathrm{BC}_{5} \mathrm{~F}_{6}$ individual plants were identified for NIL development.

vi) WH 542*5/HP1531: The $\mathrm{BC}_{5} \mathrm{~F}_{5}$ population derived from WH 542*5/HP 1531 cross was sown as progenies in the field. A total of 105 progenies were sown. In each progeny, a total of 4-5 ear heads were inoculated per plant. The inoculated ear heads were harvested and threshed manually and per cent Karnal bunt infection was calculated (Table 8). Out of these 105 progenies, two progenies was homozygous resistant, 96 were heterozygous while seven were homozygous susceptible. From these ten extreme resistant and ten extreme susceptible progenies were identified for NIL establishments. The selected resistant progenies showed a range of Karnal bunt infection from zero to 4.35 per cent. Selection for extreme susceptible progenies was also done on the basis of per cent Karnal bunt infection. All the selected plants had a Karnal bunt score of $>50.00$ per cent. From these individual plants were identified for NIL development.

vii)WH 542*5/W485: The $\mathrm{BC}_{5} \mathrm{~F}_{5}$ population derived from $\mathrm{WH} 542 * 5 / \mathrm{W} 485$ cross was sown as progenies in the field. A total of 182 progenies were sown. In each progeny, a total of 4-5 ear heads were inoculated per plant. The inoculated ear heads were harvested and threshed manually and per cent Karnal bunt infection was calculated (Table 9). Out of these 182 progenies, only six were homozygous resistant, 163 were heterozygous, while 13 were homozygous susceptible. From these ten extreme resistant and ten extreme susceptible progenies were identified for NIL establishments. The selected resistant progenies showed a range of Karnal bunt infection from zero to 3.82 percent. Selection for extreme susceptible progenies was also done on the basis of per cent Karnal bunt infection. All the selected plants had a Karnal bunt score of $>50.00$ percent. From these progenies individ- 
ual plants were identified on the basis of per cent Karnal bunt infection of individual progeny and average score of the progenies for NIL development.

The NILs established in the present study can be utilized in breeding resistance to Karnal bunt, which is becoming a threat to India's wheat exports. The donor base has been broadened by including six established as well as diverse donor stocks in the background of high yielding wheat varieties PBW 343 and WH542. Cultivars PBW343 and WH542 have susceptibility to Karnal bunt. Recently some of these NILs were evaluated for yield and agronomic performance (Kumar et $a l ., 2014$ ) and some of the lines were not only resistant to Karnal bunt, but also out yielded the parental lines. Further these NILs can be used for more precise genetic analysis due to minimum background noise as they are derived after six generations of backcrossing. Bala et al., (2015) discussed the genetics of Karnal bunt resistance in KBRL 57 as Karnal bunt resistant stock, which provided an insight into the genes involved. Further molecular marker analysis has detected QTL of relatively small effect and mostly with significant QTl-Environment interactions (Nelson et al., 1998, Sukhwinder-Singh et al., 2003, SukhwinderSingh et al., 2007). NIL based resistance gene mapping followed by use of NIL derived micro RILs for fine mapping can minimize background noise and improves QTL identification. There has been so far a single report of Karnal bunt near isogenic lines in the background of wheat variety PBW343 to be used for genetic and molecular analysis (Sehgal et al., 2008). In the current scenario of climate change Karnal bunt disease is gaining importance and threatening the prospects of wheat export. Availability and further utilization of these diverse sources of resistance to Karnal bunt comes as a boon for Indian wheat breeding programs.

\section{Conclusion}

Accumulation of diverse genes for resistance represents another option for raising the KB resistance levels in bread wheat. Presence of distinct resistance genes in the donor stocks and prevalence of additive gene action as discussed later under genetics of resistance, makes this a viable option. These KB-free lines developed in the background of PBW343 and WH542 probably have resistance factor against a wider spectrum of isolates / environments. Various genetic stocks such as KBRL22 and KBRL57 with high degree of resistance, derived from resistant $\mathrm{x}$ resistant cross have been registered with National Bureau of Plant Genetic Resources and are being used in various wheat breeding programs. This development of Karnal bunt resistant near isogenics lines in the background of high yielding wheat varieties such as PBW 343 and WH 542 holds importance as no such study has been reported in recent past in India.

\section{ACKNOWLEDGEMENTS}

The authors acknowledge the institutional and financial support for carrying out these studies at PAU, Ludhiana.

\section{REFERENCES}

Aujla, S.S., Grewal, A.S., Gill, K.S. and Sharma, I. (1982). Artifical creation of Karnal bunt disease of wheat. $\mathrm{Ce}$ real. Res. Commun., 10: 171-176.

Aujla, S.S., Sharma, I., Gill, K.S. and Grewal, A.S. (1985). Variable resistance in wheat germplasm to Neovossia indica. Proc $3^{\text {rd }}$ National Seminar Genet Wheat Improv. IARI Regional Research Station, Flowerdale, Shimla, Himachal Pradesh, India.

Bala, R., Kumar, S., Bains, N.S. and Sharma, I. (2015). Development of disease resistant bread wheat (Triticum aestivum) line in background of PBW 343 and genetics of Karnal bunt-free trait. Indian Phytopath., 68(1): 42-44.

Duran, R. and Cromarty, R. (1977). Tilletia indica: a heterothallic wheat fungus with multiple alleles controlling incompatibility. Phytopathology 67: 812-815.

Gill, K.S., Randhawa, A.S., Aujla, S.S., Dhaliwal, H.S., Grewal, A.S. and Sharma, I. (1981). Breeding wheat varieties resistant to Karnal bunt. Crop Improv., 8: 73-80.

Gill, K.S., Aujla, S.S. and Sharma, I. (1993). Karnal bunt and Wheat Production. pp 1-153. Punjab Agricultural University, Ludhiana, India.

Krishna, A. and Singh, R.A. (1982). Effect of physical factors and chemicals on the teliospore germination of Neovossia indica. Indian Phytopath., 35(3): 448-455.

Kumar, S., Bala, R., Mishra, C.N., Gupta, V., Singh, Y.P., Singh, S., Bains, N.S., Saharan, M.S., Tiwari, V. and Sharma, I. (2014). Yield evaluation of Karnal bunt Near Isogenic Lines (NILs) developed in the background of wheat variety PBW 343. Crop Improv., 41(1): 21-25.

Mitra, M. (1931). A new bunt on wheat in India. Ann. App. Biol., 18: 178-179.

Nelson, J.C., Autrique, J.E., Fuentes-Davila, G. and Sorrells, M.E. (1998). Chromosomal location of genes for resistance to Karnal bunt in wheat. Crop Sci., 38: 231-236.

Fuentes-Davila, G. and Rajaram, S. (1994). Sources of resistance to Tilletia indica in wheat. Genetics, 50: 205-209.

Sansford, C.E. Baker, R.H.A. and Brennan, J.P. (2008). The new Pest Risk Analysis for Tilletia indica, the cause of Karnal bunt of wheat, continues to support the Quarantine status of the pathogen in Europe. Plant Pathology 57: 603-611.

Sehgal, S.K., Kaur, G., Sharma, I. and Bains, N.S. (2008). Development and molecular marker analysis of Karnal bunt resistant near isogenic lines in bread wheat variety PBW343. Indian J, Genet., 68 (1):21-25.

Sharma, I. and Nanda, G.S. (2002). Factors affecting teliospore viability of Neovossia indica. J. Res. Punjab Agric. Univ., 39: 15-27.

Sharma, I., Bains, N.S. and Nanda, G.S. (2004). Inheritance of Karnal bunt-free trait in bread wheat. Plant Breed., 123 (1): 96-97.

Sharma, I., Bains, N.S. and Sharma, R.C. (2007). Karnal bunt resistance - an overview. Journal of Wheat Research 1: (1) 68-81.

Sharma, M., Nanda, G.S., Sharma, I. and Sohu, V.S. (2001). Inheritance of resistance to Karnal bunt (Neovossia 
indica) in bread wheat (Triticum aestivum L.). Crop Improv., 28 (2): 207-213.

Sharma, A.K., Saharan, M.S., Sharma, I., Singh, M., Kundu, S., Phogat, B.S., Meeta, M., Shikha, Deep, Srivastava, K., Singh, S.P., Vaish, S.S., Mishra, P.C., Honrao, B.K., Kalappanavar, I.K., Solanki, V.A., Srinivasan, K.J., Sherry, R. and Tyagi, R.K. (2012). Identification of diverse sources of multiple disease resistance in wheat. Indian J. Plant Genet. Resour., 25(3): 238-245.

Sharma, I. (2004). Management of Karnal bunt disease of wheat. National Symposium on 'Plant Disease Development, Challenges and Strategies', held at PAU, Ludhiana, during 4-5 February 2003.

Smilanick, J.L., Hoffmann, J.A., Cashion, N.L. and Prescott, J.M. (1987a). Evaluation of seed and foliar fungicides for the control of Karnal bunt of wheat. Plant Disease 71: 94-96.

Smilanick, J.L., Hoffmann, J.A. and Prescott, J.M. (1987b). Control of Karnal bunt with foliar fungicides, 1986. Fungicide Nematicide Tests, 42: 96.

Singh, D.V., Srivastava, K.D. and Joshi, L.M. (1985). Present status of Karnal bunt of wheat in relation to its distribution and varietal susceptibility. Indian Phytopath, 38(3): 507-515.

Sukhwinder-Singh, Brown-Guerdia, G.L., Grewal, T.S., Dhaliwal, H.S., Nelson, J.C., Singh, H. and Gill, B.S. (2003). Mapping of a resistance gene effective against Karnal bunt pathogen of wheat. Theor. Appl. Genet., 106: 287-292.

Sukhwinder-Singh, Sharma, I., Sehgal, S.K., Bains, N.S., Guo, Z., Nelson, J.C. and Bowden, R.L. (2007). Molecular mapping of QTLs for Karnal bunt resistance in two recombinant inbred populations of bread wheat. Theor. Appl. Genet., 116: 147-154.

Villareal, R.L., Mujeeb-Kazi, A., Fuentes-Davila, G. and Rajaram, S. (1994). Resistance to Karnal bunt in synthetic hexaploid wheat derived from Triticum turgidum $x$ T. tauschiii. Plant Breed., 112: 63-69.

Villareal, R.L., Mujeeb-Kazi, A., Fuentes-Davila, G. and Rajaram, S. (1996). Inheritance of resistance to Tilletia indica (Mitra) in synthetic hexaploid wheat x Triticum aestivum crosses. Plant Breed., 114: 547-548.

Warham, E.J. (1986). Karnal bunt disease of wheat - A literature review. Trop. Pest Mgmt., 32: 229-242. 